\title{
Sport Volunteering in the 11th ASEAN School Games 2019: Implementation and Constraints
}

\author{
Irana Mery Alviana ${ }^{1}$, Limpad Nurrachmad ${ }^{2}$, Said Junaidi ${ }^{3}$ \\ \{iranamery.a@gmail.com ${ }^{1}$, limpad.edu@mail.unnes.ac.id ${ }^{2}$, said.ikor@mail.unnes.ac.id ${ }^{3}$ \} \\ Universitas Negeri Semarang, Central Java, Indonesia ${ }^{1,2,3}$
}

\begin{abstract}
The purpose of this study was to describe the implementation of the 2019 ASEAN School Games volunteering program and the constraints faced by volunteers during the event. In conducting this study, the researchers used a qualitative approach. The instruments used in this study were observation, interviews, and documentation. The subjects of this research include the chairperson of the 2019 ASEAN School Games's organizing committee, the volunteer coordinator for the 2019 ASEAN School Games, and 10 volunteers of the 11th ASEAN School Games. The results showed that the organizing committee of the 11th Asean School Games was not optimal in making preparations as well as managing sport volunteers that brought about various constraints for sport volunteers. Therefore, the organizing committee is expected to be better in the future in terms of managing sports volunteers, including in the recruitment process.
\end{abstract}

Keywords: Implementation, Sport Volunteer, ASEAN School Games.

\section{Introduction}

One of the international level sporting events that is held annually is the ASEAN School Games or commonly referred to as ASG. This sporting event was attended by high schools in the Southeast Asia region such as Indonesia, Brunei Darussalam, Singapore, Thailand, Vietnam, Malaysia, Philippines, Laos, Cambodia, and Myanmar. The ASEAN School Games are held in turns in each country involved. Indonesia is recorded to have hosted the 4th ASEAN School Games in 2012 in Surabaya, East Java. In 2019 Indonesia will again host the 11th ASEAN School Games and will be held in Semarang, Central Java from 17 to 25 July 2019. As the host, Indonesia should prepare everything optimally. The implementation of the ASEAN School Games in 2019 involved the Ministry of Youth and Sports of the Republic of Indonesia (Kemenpora), the Central Java Provincial Government, and the Central Java Youth, Sports and Tourism Office (Disporapar), and several universities. Preparations that must be considered include the preparation of facilities and infrastructure, administration, accommodation, and last but not least, sports volunteers.

As the host, the sport event organizer must have a standard sports administration as well as the preparations made as mentioned, including the organizational structure of the organization, competent sports personnel, work plans and programs, financing units, implementation schedules, administration and management systems, service systems, as well as security and safety systems.[1]. In the effort of succeeding a sports event such as the ASEAN School Games, sports volunteers who are willing and able to work well are needed, 
so that the recruitment process for sports volunteers is crucial and needs to be carefully prepared.

It seems that the recruitment of sports volunteers needs to be done so that the volunteers who work later meet the predetermined criteria or standards. In carrying out the recruitment process, it needs to be considered that volunteer involvement is not only driven by individual factors but also by the institutional context (for instance, sport organization, sport event; Penner, 2002). In order for the implementation of activities to run smoothly and according to plan, support from the institutional context is needed to motivate sports volunteers [2].

Sports volunteer are an important part of a prestigious sporting event because with sports volunteers, a sporting event becomes more meaningful. Becoming a sports volunteer is not easy, especially for large events such as the ASEAN School Games which is an international class event. To become a sport volunteer, the candidates must fulfill all the requirements such as having the ability to speak foreign languages, especially English, being able to communicate well, having an interest in sports, knowing things in the sport that he/she is interested in, and so on.

Volunteers themselves make a big contribution in a sports event. With the presence of volunteers, the organizing committee's workload will be less and are well accommodated. Volunteers and staff or organizers will always be needed continuously to work together and function as a team. Without work assistance from the volunteer team, sports events will not run well because they have a significant role in managing a sport event[3].

At initial observations, the researchers found several discrepancies in the implementation of the 2019 ASEAN School Games Volunteering, negative statements emerged from volunteers that would cause constraint such as volunteers did not understand their duties, did not know what to do during the event, did not understand the actual rundown of the event so that volunteers were often misled in the event. The distribution of information provided was also unclear and not specific. when the implementation was not in accordance with the direction, the schedule of activities suddenly changed, there was a mismatch between the regulations and rules announced by the committee and the facts occurred in the main event.

Volunteers have a big influence on the success of the implementation. The constraints experienced by volunteers would surely affect the quality of the event. Mowen et al. (2005) examines the stability of constraints over time. They compared constraint studies from the Cleveland area from 1991 and 2001 and analyzed changes in perceived constraints over time. Despite finding small differences in demographics between the two samples, the perceptions of constraints remained very similar over time. In the results of the study, it was stated that many volunteers experienced constraints on the part of structural constraints, such as a lack of time, money, transportation, etc. [4].

Based on the background of the above problems, the researcher aims to find out how the organizing committee implemented the 2019 ASEAN School Games volunteering and to find out what constraints the volunteers experienced during the 2019 ASEAN School Games.

\section{Method}

This research method used in this study was a qualitative research approach. The instruments used in this study were observation, interviews, and documentation. The results of the research were then analyzed by reducing data, presenting data, and drawing conclusions. 


\section{Result and Discussion}

The results of this study contain the implementation or application of the 2019 ASEAN School Games committee and the constraints experienced by the 2019 ASEAN School Games volunteers during the activity. The research data were obtained from 12 respondents who were the subjects of this study that comprised 1 committee, 1 volunteer coordinator, and 10 volunteers for the 2019 ASEAN School Games.

\subsection{Implementatin of Sport Volunteering in 11th ASEAN School Games 2019}

Recruitment. The recruitment mechanism implemented is through the delivery of sports volunteer recruitment information to campuses or universities in the Semarang area. This is done because the main target for volunteering is students who are competent, especially in the field of sports. Previously, the committee held a coordination meeting with the Ministry of Youth and Sports regarding the number of volunteers needed. Furthermore, the local committee holds a coordination meeting with universities in Semarang to discuss the requirements or criteria that have been set.

The determined requirements for sport volunteers include mastering foreign languages, especially English as an international language, then understanding the sports that would be contested in the 2019 ASEAN School Games and knowing the location of sports venues in Semarang because their duties are not only as a liaison officer but also as a forefront in promoting the world of tourism in Central Java, especially the city of Semarang. Referring to this, Indonesia as the host certainly not only has the motivation to become the overall champion but also wants to show and introduce the richness of tourism and culture in Indonesia. Thus, Indonesia will be better known by all countries in the Southeast Asian region. Sports volunteers are required to have the ability to introduce Indonesia through sports events and build awareness of visitors so that they can perceive Indonesia with all its wealth into a good brand image for the development of all sectors in this country [5].

The volunteer recruitment process was administered in about two months. The recruitment process included the information announcement to schools, universities, and public, the administration selection, and the volunteer tests. Students who register are required to take part in the selection, each campus has determined several stages of selection which are carried out according to the procedures or criteria set by the committee.

Based on the requirements, students / prospective volunteers have no difficulty in registering but there were several complaints that arose from students / prospective volunteers, it was said that the recruitment was administered in a non-transparent manner since many volunteer candidates could pass the recruitment process even though they did not meet the predetermined criteria for reasons that did not. make sense. In other words, it was also found some candidates that did not pass the recruitment process even though they were competent and met the criteria or standard that had been approved by the organizing committee due to the quota limitation.

The Duties of a Sport Volunteer. The volunteers who passed were then placed in various work groups such as the accommodation division, which served as liaison officer between the participants and the hotel. The accommodation division duties in detail, such as providing hotel room information that has been prepared by the organizer to the participants. Next, the consumption division, the consumption division is in charge of managing the meal schedules of the participants. The transportation division is supposed to prepare vehicles/shuttles that 
will be used or needed during the event such as making communication with bus drivers so that they are always alert in providing transportation services for participants and team's officials. The sports division is in charge as a companion for the participants or contingents such as picking up the contingent, informing meal schedules, finding training places, directing locations or places that participants want to visit, becoming tour guides while on city tours, and assisting or accompanying the return of the contingent. This task is given to volunteers who have been adjusted to the volunteers' abilities, but some volunteers still do not know and understand the tasks given because the committee does not provide the term of reference of the volunteer's task and duties.

The term of reference is then very important before volunteers carry out their duties. By providing clear directions \& guidance, volunteers would be able to accomplish their duties properly and will have a good effect on the event as stated that guidance and training focuses on the suitability of volunteer work according to the volunteer duties can increase the satisfaction of all components in an event [6].

Volunteer Enhancement Training. The volunteer enhancement training held was not in accordance with what the volunteers expected. Some volunteers who attended the training session were not satisfied because the material provided was not suitable with what was happening in the field, especially for some volunteers who had never volunteered at a sporting event. The volunteer enhancement training was carried out for two days by presenting materials that were too general and not specific. The volunteers were only given a general description of the tasks and events and were more impressed like an intermezzo. The training materials provided were only related to the number of participants, the countries involved, the venues to be used, the transportation to be used, and the route for taking the eternal flame torch where these activities are not actually the duty of a volunteer.

The researcher then concluded that there was a mismatch between the committee's plan during the volunteer enhancement training and the actual event context. This was shown by the fact that there were still many volunteers who were misled and misguided regarding their respective main duties and functions while working. Supposedly, the organizing committee should prepare the main duties and functions of each volunteer in detail so that there would not be any constraints at work [7].

Sport Volunteer Management in ASG 2019. Before the committee started working with the volunteers, especially in the 11th Asean School Games 2019, it should be highly beneficial for the committee to spend some time with them to figure out who they were as people. Getting to know what brought them there, what was their driving force, what did they like/dislike. Knowing them better might really help the committee in not just knowing what strategies would work best with them but also make them feel heard. However, it turned out that the coordinator of volunteers or the committee of ASG 2019 did not implement what they should do. It was found from one of the interviews with the volunteers as stated below;

"We were not given any kind of special training for volunteers to understand specific roles and tasks, there was no good coordination between volunteer coordinators and volunteers. We were only given a softfile to learn which contained the jobdesk of each division and even then it was given suddenly. The match schedule for each contingent was also informed suddenly so that we had difficulty providing optimal service both on the field and outside the field". 
Another important point is to have clear objectives \& roles for the volunteers. The committee must avoid as much as possible any vagueness around what the volunteers are expected to do. This would make sure they know what they should do and what is expected of them to deliver. It will also help the committee avoid any confusions and also make volunteers feel comfortable as they would have a clear understanding of what they are supposed to deliver over a period of time. Yet, the reality in the field showed some improper manner as revealed below;

"At the time of volunteer training session, we were not given written rules
regarding what a volunteer could do and what a volunteer could not do while on
duty. The rules and norms as a sports volunteer are only given orally during the
training, so we cannot learn them in detail and comprehensively"

This was reinforced by the discovery of several volunteers who did bad things such as smoking while on duty, leaving without permission during working hours, and asking participants / contingents for tips. Thus, it can be concluded that the volunteer management pattern in ASG 2019 cannot be said to be well-managed because there is still a mismatch between what should be done and the facts that occur in the field.

Sport Volunteer Facilities. The committee provided some volunteer kit to support the volunteers during the event, such as two polo shirts, transportation money, sporty vests, bags, hats, and ID cards. The committee did not specifically prepare a place to stay for volunteers. However, the committee prepared several hotel rooms that can be used or functioned as transit rooms for volunteers during the event. Therefore, most of the volunteers chose to return to their homes due to the limited accommodation facilities for volunteers.

The transportation facilities provided by the committee were also very minimal. In other words, the committee only provided buses or shuttle for use during event such as picking up participants from the hotel to the venue or vice versa. Most volunteers used private vehicles, unless during the event there were empty seats so that volunteers could join the bus/shuttle to accompany the participants.

\subsection{Volunteers' Constraints in 11th ASEAN School Games 2019}

Language Constraint. Constraints that occurred during the event were that some volunteers experienced problems in language, or we called it as language constraint when communicating with participants from foreign countries. This was due not only to the volunteers 'limited English skills, but also the participants' limited English skills. Most of the language constraint in communicating was experienced by volunteers when they assisted Thailand, Myanmar, Vietnam, the Philippines, Laos and Cambodia. To overcome this language constraint the participants and volunteers were assisted by the google translation application. Meanwhile, volunteers accompanying participants from Malaysia, Singapore and Brunei did not experience difficulties because they could communicate using Malay and even some of the participants wanted to learn Indonesian language.

Communication Constraint. Miscommunication often occurred between volunteers and the committee. This is because the information provided by the committee was often late and not accordance the reality on the field, which makes volunteers confused. Information that should have been passed on to the contingent became ineffective and tended to be too late. 
Miscommunication also occurred among volunteers. Some of the interviewed volunteers said there were frequent delays in information provided and there were lacks of coordination, as it was happened to volunteers in sports and transportation division related to contingent / participant pick-up schedules.

Facilities Constraint. Constraints related to facilities included housing for volunteers, sport venues, and transportation. This is vital for a sport event. Some volunteers did get hotel room facilities, but the numbers of hotel rooms were very limited. Those who were lucky to get a hotel room because one of the contingents left early so that the room could be used and that too had to alternate with other volunteers. Many volunteers did not get a place to stay, such as experienced by one of the volunteers. It was said that there were 18 volunteers who were supposed to have only one room left, which made some of them prefer to return to their homes or boarding houses.

One of the volunteers from Sepak Takraw said that the venue used was the one used from the previous event, the 18th Asian Games. Venue is the most important thing in a sports event, without the availability of venues, a competition will not run smoothly. The venues used must also meet international standards because the ASEAN School Games is an international event. The availability of venues that are according to standards will add positive value to Indonesia as the host, which can show that Indonesia is also able to compete to display and provide sports facilities. Thus, it would also have an influence on the development of sports itself.[8].

Transportation Constraint. Transportation was one of the constraints that happened during the 2019 ASG event. The availability of transportation for participants and the committee seems insufficient to facilitate. This showed that the committee was not quite ready to provide transportation services for the participants and the committee. Some volunteers have complained about pick-up buses / shuttles that were often late due to the lack of availability. The use of transportation was quite important to provide transportation services for participants to travel from the hotel to the venue and vice versa, as well as taking participants to tourism spots in Semarang and surroundings.

Based on these findings, the researcher can conclude that volunteers have significant constraints in terms of transportation and communication, as accumulated in the following diagram.

\section{Kendala}

\section{Bahasa - Transportasi $=$ Akomodasi $=$ Komunikasi}

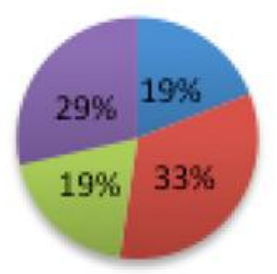

Fig. 1. Volunteers' Constraints in ASEAN School Games 2019 
Constraints that arose would certainly reduce the effectiveness and success of an event. To minimize the constraint that occurred, the committee should pay more attention to the direction and guidance for sports volunteers, especially in terms of facilities and transportation, so that volunteers would work optimally and felt satisfied because they had been part of the success of a large event. As the existing theory states that volunteers are satisfied with what they are doing because of several factors that are directly controlled by the event organizer including transportation, food and accommodation, as well as other factors such as workload (Doherty, 2003; Elstad, 1996; Ralston et al., 2004)[9] and as revealed by Houlihan (2001, p. 1)[10] " as a source of empowerment for citizens and as civil society institutions in the sports and recreation professions, they themselves have a significant contribution to make ".

\section{Conclusion}

Based on the findigs discussion of research, it can be concluded that in the 2019 Asian School Games event, the committee did not apply the rules or regulations of sports management including in terms of managing sport volunteers. It brings about several constraints for volunteers. These constraints include confusion of volunteer duties, confusion of the schedule of event given, communication, transportation and housing facilities.

Acknowledgments. On this occasion, the author would like to thank all management of the Department of Sport Science, Faculty of Sport Science, Universitas Negeri Semarang, especially Dr. Said Junaidi, M.Kes., and Limpad Nurrachmad, S.Pd., M.Pd. who have provided input as well as guidance so that I was able to complete this research. Last but not least, my parents and friends who have also supported me with motivation and encouragement.

\section{References}

[1] A. Kristiyanto, "Standarisasi penyelenggaraan event olahraga," pp. 1-13, 2008.

[2] P. Wicker and K. Hallmann, "A multi-level framework for investigating the engagement of sport volunteers," no. February 2015, pp. 37-41.

[3] G. Pauline, J. S. Pauline, G. Pauline, and J. S. Pauline, "Volunteer motivation and demographic influences at a professional tennis event," 2011.

[4] R. L. G. Iii, "Volunteer Motivations And Constraints Among Undergraduate College Students," 2009.

[5] R. I. Putra, "Strategi membangun nation branding indonesia dalam asian games jakarta- palembang 2018," pp. 72-80, 2018.

[6] D. De Cremer, "Volunteer work in youth organizations: Predicting distinct aspects of volunteering behavior from self- and other-oriented motives. Ilse," pp. 1-32.

[7] I. Marwan, A. A. Rahmat, and A. Rohyana, "Pelatihan Pengelolaan Manajemen Event Pertandingan Olahraga Untuk Pengurus Dan Anggota Koni Kota Tasikmalaya,” J. Pengabdi. Siliwangi, vol. 4, pp. 179-185, 2018.

[8] I. Wahidah, "Kontribusi Manajemen Fasilitas Dan Mutu Layanan Terhadap Prestasi Olahraga Sepakbola (Studi pada Mahasiswa Pendidikan Jasmani Kesehatan dan Rekreasi FKIP UNSIL Tasikmalaya)."

[9] Anonim, "Event volunteer role ambiguity," pp. 1-39.

[10] R. Hoye, G. Cuskelly, C. Auld, and P. K. and K. Misener, Sport Volunteering. 2020. 